\title{
Glacier area changes in the central Chilean and Argentinean Andes 1955-2013/14
}

\author{
JEPPE K. MALMROS, ${ }^{1}$ SEBASTIAN H. MERNILD, ${ }^{2,3}{ }^{\text {RYAN WILSON },{ }^{4} \text { JACOB C. YDE, }}{ }^{2}$ \\ RASMUS FENSHOLT ${ }^{1}$
}

\author{
${ }^{1}$ Department of Geosciences and Natural Resource Management, University of Copenhagen, Copenhagen, Denmark \\ ${ }^{2}$ Faculty of Engineering and Science, Sogn og Fjordane University College, Sogndal, Norway \\ ${ }^{3}$ Direction for Antarctic and Subantarctic Programs, Universidad de Magallanes, Punta Arenas, Chile \\ ${ }^{4}$ Department of Geography and Earth Sciences, Aberystwyth University, Aberystwyth, UK \\ Correspondence: Jeppe Kjeldahl Malmros <vwh636@alumni.ku.dk>
}

\begin{abstract}
To improve our knowledge of glacier area changes in the central Chilean and Argentinean Andes $\left(32^{\circ} 9^{\prime} \mathrm{S}-33^{\circ} 4^{\prime} \mathrm{S}\right)$, two new glacier inventories from 1989 to $2013 / 14$ are compared with a reinterpreted inventory from 1955. Comparisons show glacier area retreat of $30 \pm 3 \%$ since 1955, decreasing from 134 to $94 \mathrm{~km}^{2}$ in 2013/14, whilst the annual rate of area loss showed a small increase (insignificant) between the periods of 1955-1989 and 1989-2013/14. Separate analysis of the 1989 and 2013/14 inventories, including a larger sample, revealed a higher rate of glacier change compared with the smaller samples of these inventories. Additionally, an analysis at $\sim 5$ year intervals for six major glaciers (1955-2013) indicates large variability in response times and area loss magnitudes. Glacier Olivares Alfa, for example, lost $63 \%$ of its ice area, while the Juncal Norte Glacier lost only 10\% (1955-2013). The findings from this study improve our current knowledge base concerning widespread glacier decline in the southern Andes, and furthers monitoring efforts in this poorly described region of the world, a region containing vital water resources for populated areas in South America.
\end{abstract}

KEYWORDS: climate change, glacier delineation, glacier fluctuations, glacier mapping, remote sensing

\section{INTRODUCTION}

In line with most regions of the world, glaciers in southern South America have retreated and thinned in response to climate changes since the end of the Little Ice Age (LIA) (Masiokas and others, 2006; Le Quesne and others, 2009; Mernild and others, 2015). For the relatively well-examined southern Patagonia region, studies have revealed post-LIA glacier area losses in the order of $11-14 \%(\sim 1870-2011)$ (Davies and Glasser, 2012; Falaschi and others, 2013) and area change rates of $-0.2 \% \mathrm{a}^{-1}$ in recent years $(2000 / 02-$ 2008/10) (White and Copland, 2015). To the north, in the semi-arid central Chilean and Argentinean Andes, only relatively few studies have coupled glacier changes with climate dynamics (e.g., Lliboutry, 1998; Leiva, 1999; Pellicciotti and others, 2007, 2008, 2014) showing that glaciers in this region are shrinking and losing mass.

The glacier inventories available for the central Chilean and Argentinean Andes, compiled from a wide variety of sources (e.g. aerial photography, satellite imagery and historic maps), are currently relatively few in number, with most including only a small number of glaciers (e.g., Lliboutry, 1956; Marangunic, 1979; Valdivia, 1984; Garin, 1987; Aniya and others, 1996; Leiva, 1999; Nicholson and others, 2009; Rabatel and others, 2011). Although indicating glacier retreat, these inventories and glacier change studies cover different time intervals throughout the 20th and 21st centuries, making direct glacier comparisons difficult. Due to these limitations, detailed assessments of long-term glacier changes in the central Chilean and Argentinean Andes (besides length changes) are to a large extent still missing (Pellicciotti and others, 2014); a circumstance that is limiting our understanding of glacier/climate interactions in this region.
Climate conditions in this part of the Chilean and Argentinean Andes $\left(31-35^{\circ} \mathrm{S}\right)$ are semi-arid and Mediterranean in type (Lliboutry, 1998), with regional-scale weather conditions being largely controlled by the seasonal displacement of a high-pressure cell above the southeastern Pacific Ocean (Rutllant and Fuenzalida, 1991), which inhibits precipitation in summer and allows for the passage of westerlies and subsequent frontal precipitation during Austral winters (May-August) (Garreaud and others, 2009). Also, precipitation amounts two to three times greater than at sea level are present at west-facing Andes slopes due to the orographic uplift of low-level air, while dry leeward conditions prevail on eastern Andes slopes (Garreaud and others, 2009). Precipitation amounts between $30^{\circ} \mathrm{S}$ and $35^{\circ} \mathrm{S}$ are influenced by the El Niño Southern Oscillation (ENSO), with above average annual precipitation totals during $\mathrm{El}$ Niño events and below average totals during La Niña events (e.g. Rutllant and Fuenzalida, 1991; Escobar and others, 1995; Leiva, 1999; Montecinos and Aceituno, 2003; Garreaud and others, 2009; Gascoin and others, 2011; Mernild and others, 2015). ENSO events have also been linked to increases in winter snowfall and a higher frequency of avalanches in the central Chilean Andes (Masiokas and others, 2006; McClung, 2013). Evidence suggests that precipitation patterns in the central Chilean and Argentinean Andes have undergone significant changes over the past 30 year (Pellicciotti and others, 2007). Higher frequencies of above average winter snow accumulation have been observed in the central Andes Cordillera since 1976 (Masiokas and others, 2009), with particularly large snow accumulation events occurring between 1980 and 1985 (Masiokas and others, 2006). From the mid-1970s to 
2001, for example, large precipitation events have become less frequent but more intense (Carrasco and others, 2005). These precipitation changes, together with observed reductions in seasonal snow cover, have resulted in reduced levels of runoff in the central Chilean Andes (Pellicciotti and others, 2007). In addition, an air temperature increase of $\sim 0.25^{\circ} \mathrm{C}$ per decade, has been observed for the central Andes between 1975 and 2001 (Rosenbluth and others, 1997; Falvey and Garreaud, 2009), resulting in a rise of the $0^{\circ} \mathrm{C}$ isotherm by $\sim 120 \mathrm{~m}$ in winter and $\sim 200 \mathrm{~m}$ in summer (Carrasco and others, 2005).

Central Chilean and Argentinean glaciers constitute important water resources for downstream populations (Mernild and others, 2015). Although river runoff in this region is mainly sourced from snowmelt (Favier and others, 2009), during the late ablation season when seasonal snow has melted, runoff from glacier melt increases in importance. Glacier meltwater is thus an important freshwater resource for urban and agricultural areas. In the Rio Maipo basin, the main river basin of Region Metropolitana, water resources are reduced during dry summers especially when preceded by episodic winter droughts (Meza and others, 2012). During such events up to $67 \%$ of the river discharge in Rio Maipo originates from glacier ablation in the Chilean central Andes (Peña and Nazarala, 1987).

Previous work has reported glacier changes at Juncal Sur, Olivares Beta, Olivares Gamma and Olivares Alfa in the Rio Olivares basin (Lliboutry, 1998; Masiokas and others, 2009; Gacitua and others, 2015), and glacier Juncal Norte in the Aconcagua basin (Pellicciotti and others, 2007, 2008; Bown and others, 2008). These studies provide information on area and length changes, thinning rates and thermal regime. Additional studies for larger glaciers in the upper part of the Rio del Plomo basin include information on length and hypsometry (Llorens and Leiva, 1995; Leiva, 1999). Overall, these studies have indicated that glaciers in the region are thinning and losing area as a consequence of changing climatic conditions (Pellicciotti and others, 2014). However, consistency in mapping methods and use of imagery for these studies were, to a large extent, lacking. For some of these studies, this sadly inhibits comparability and re-usability of data.

In this study we aim to establish a foundation for future glacier monitoring studies by consistently quantifying glacier area change in one of the most glacierized areas of the central Chilean and Argentinean Andes (32 $\left.{ }^{\circ} 9^{\prime}-33^{\circ} 4^{\prime} \mathrm{S}\right)$ over a 58/59 year period between 1955 and 2013/14. Our analysis is based on a comparison between a reinterpreted version of an existing glacier inventory from 1955, derived from aerial imagery using georeferenced original aerial imagery (Marangunic, 1979), and two new glacier inventories from 1989 and 2013/14. The two new glacier inventories used were compiled from co-registered Landsat 5, Landsat 8 and GeoEye- 1 satellite imagery. In addition, we examine in detail, six of the largest glaciers, located in and around the Rio Olivares basin (in the center part of the study area), at 5 year intervals between 1955 and 2013/14 in order to gain further insight into the temporal variability of glacier change in this region.

\section{STUDY AREA}

The study area is located in the central Chilean and Argentinean Andes $\sim 50 \mathrm{~km}$ northeast of Santiago de Chile $\left(32^{\circ} 9^{\prime}-33^{\circ} 4^{\prime} \mathrm{S}\right)$, and covers an area of $1958 \mathrm{~km}^{2}$ (Fig. 1). Mountain peaks in this area reach altitudes $>6000 \mathrm{~m}$, with the central massifs marking the dividing line between two distinctly different climate systems on the east and the west of the cordillera. As of 2013/14, $2 \%$ of the study area was glacierized, including valley, mountain and cirque type glaciers varying in size from $\sim 0.05$ to $\sim 21 \mathrm{~km}^{2}$. The study area also includes a number of fully debris-covered glaciers and rock glaciers that are excluded from sampling. The majority of the 2300 individual glaciers (as of 2013/14) are located in the northern part of the study area at elevations between $\sim 2900$ and $\sim 6100 \mathrm{~m}$ a.s.I. Here, glaciers are distributed at mean elevations between $\sim 3300$ and $\sim 5500 \mathrm{~m}$ a.s.l., with the majority of the glacierized area located between $\sim 4200$ and $\sim 4500 \mathrm{~m}$ a.s.l. (Fig. 2).

Glaciers in this study area supply runoff to several important river basins including the Rio Aconcagua (north), Rio Molino (west), Rio del Plomo (sub-catchment of the Rio Tupungato) (east), and two sub-catchments of the Rio Maipo, Rio Olivares and Rio Colorado (south) (Fig. 1b). A few specific glaciers in the study area are identified as surge-type glaciers. The glacier Grande del Nevado on the eastern slopes of the Nevado del Juncal massive, for

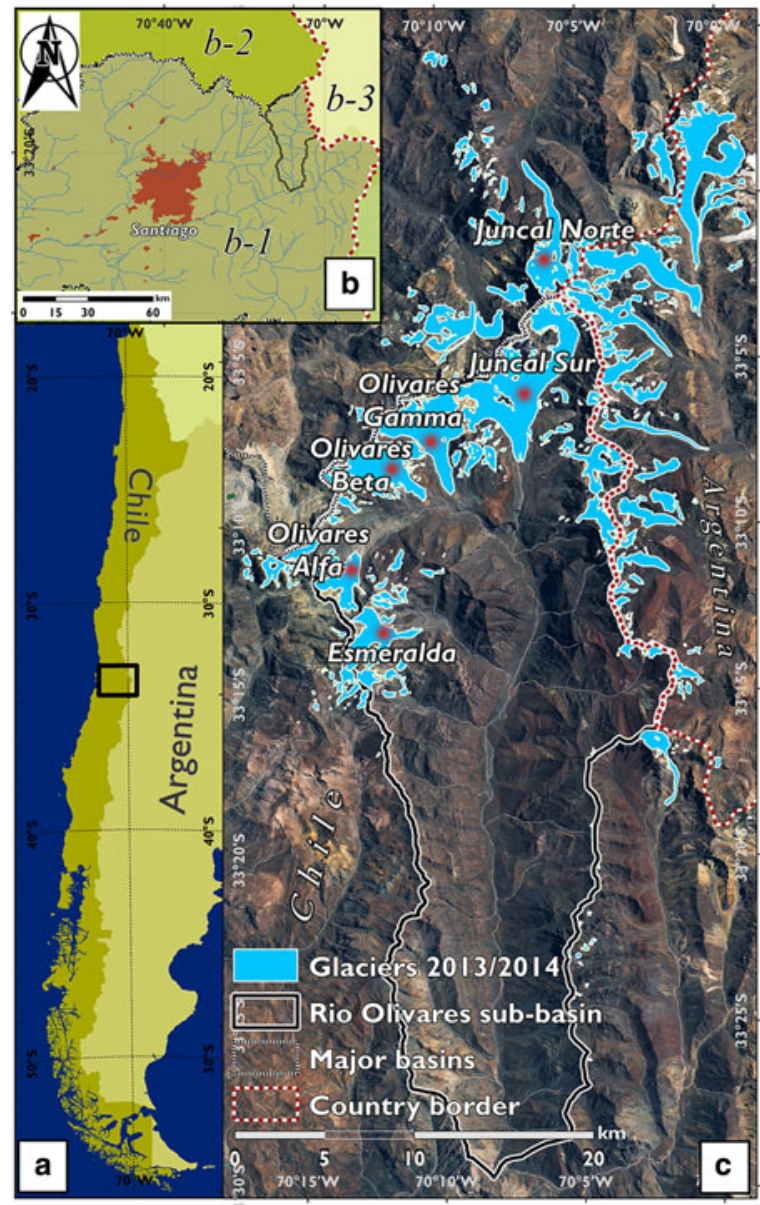

Fig. 1. (a) The location of the study site in central Chile and Argentina highlighted with a black bold rectangle. (b) The location of Rio Olivares basin and neighboring basins: $b-1$ Rio Maipo, $b-2$ Rio Aconcagua and $b-3$ Rio del Plomo. (c) The glaciers in and around the Rio Olivares basin identified in 2013/14 and highlighted in light blue. Red dots indicate the six large glaciers selected for detailed temporal analysis (image: Landsat 8, 10 February, 2014). 
example, surged in 1933 and again in 1984 (Espizúa and Lydia, 1986). Suspected surging activity was also observed at the glacier Juncal Sur on the west side of the same massive between 1946 and 1947 (Lliboutry, 1998).

\section{METHODS AND MATERIALS}

\subsection{Imagery}

Image sources include: (1) aerial photography from 1955 acquired by the Chilean military Instituto Geográfico Militar (available from Dirección General de Aguas (DGA)), (2) declassified Optical Corona spy satellite images (1967), (3) Landsat 2 - Multispectral Scanner (MSS) (1975), (4) Landsat 5 - Thematic Mapper (TM) (1985-2010), (5) Landsat 7 Enhanced Thematic Mapper Plus (ETM+) (2000-2003), (6) Landsat 8 - Operational Land Imager (OLI) (2014), (7) Advanced Spaceborne Thermal Emission and Radiometer (ASTER) $(2008,2010)$, and (8) ortho-projected GeoEye-1 satellite imagery (2013). All selected images were acquired during the late ablation season (February-April), when seasonal snow cover is at a minimum. The Corona and Landsat satellite imagery used was acquired from the USGS Earth Explorer (http://earthexplorer.usgs.gov/) and the Global Visualization Viewer (http://glovis.usgs.gov/) webportals. The 2013 GeoEye-1 scenes were acquired from DigitalGlobe (http//:www.digitalglobe.com). Elevation data were obtained from the ASTER Global DEM (GDEM) v.2 (Tachikawa and others, 2011), with a mean vertical error of $\pm 2.12 \mathrm{~m}$ over South America when compared with ICESat Geosciences Laser Altimeter System (GLAS) measurements.

Images used for the glacier subsample analysis were temporally distributed with a maximum gap of 12 years (19551967). The individual observation years include: 1955, 1967, 1975, 1985, 1989, 1994, 2000, 2002, 2008, 2010 and $2013 / 14$. For the glacier elevation changes estimated between each observation period, it should be noted that these are functions of 2-D planimetric area changes over a static raster DEM data (perimeter elevation). As the ASTER GDEM v.2 elevation data originate from best observation ASTER stereo image pairs acquired between 2000 and 2010, glacier elevations estimated prior to and after these observation years may include additional uncertainties brought about by temporal ice surface thickening and thinning. In this study these elevation changes should be seen as estimates, not ground truth measurements.

\subsection{Misclassification errors and uncertainties}

Prior to glacier mapping, each of the image datasets were coregistered to the 2014 Landsat 8 scene (using 27-35 ground control points). The resulting RMSE values varied from $\pm 2 \mathrm{~m}$ (1955 aerial imagery), $\pm 8 \mathrm{~m}(\mathrm{ETM}+)$ and $\pm 38 \mathrm{~m}$ (MSS). The RMSE values are largely dependent on image pixel resolution, with the coarsest resolutions producing the highest errors. Source image pixel resolutions ranged from $4 \mathrm{~m}$ (GeoEye-1) to $60 \mathrm{~m}$ (MMS).

Potential glacier outline delineation errors (misclassifications) were calculated following the method by Williams and others (1997). The maximum possible glacier delineation errors for the 1955, 1989 and 2013/14 inventories were calculated as $\sim 2, \sim 15$ and $\sim 4 \%$, respectively. The average delineation error for the sub-selected glaciers in the Rio Olivares basin varied from $0.3 \%$ for the 1955

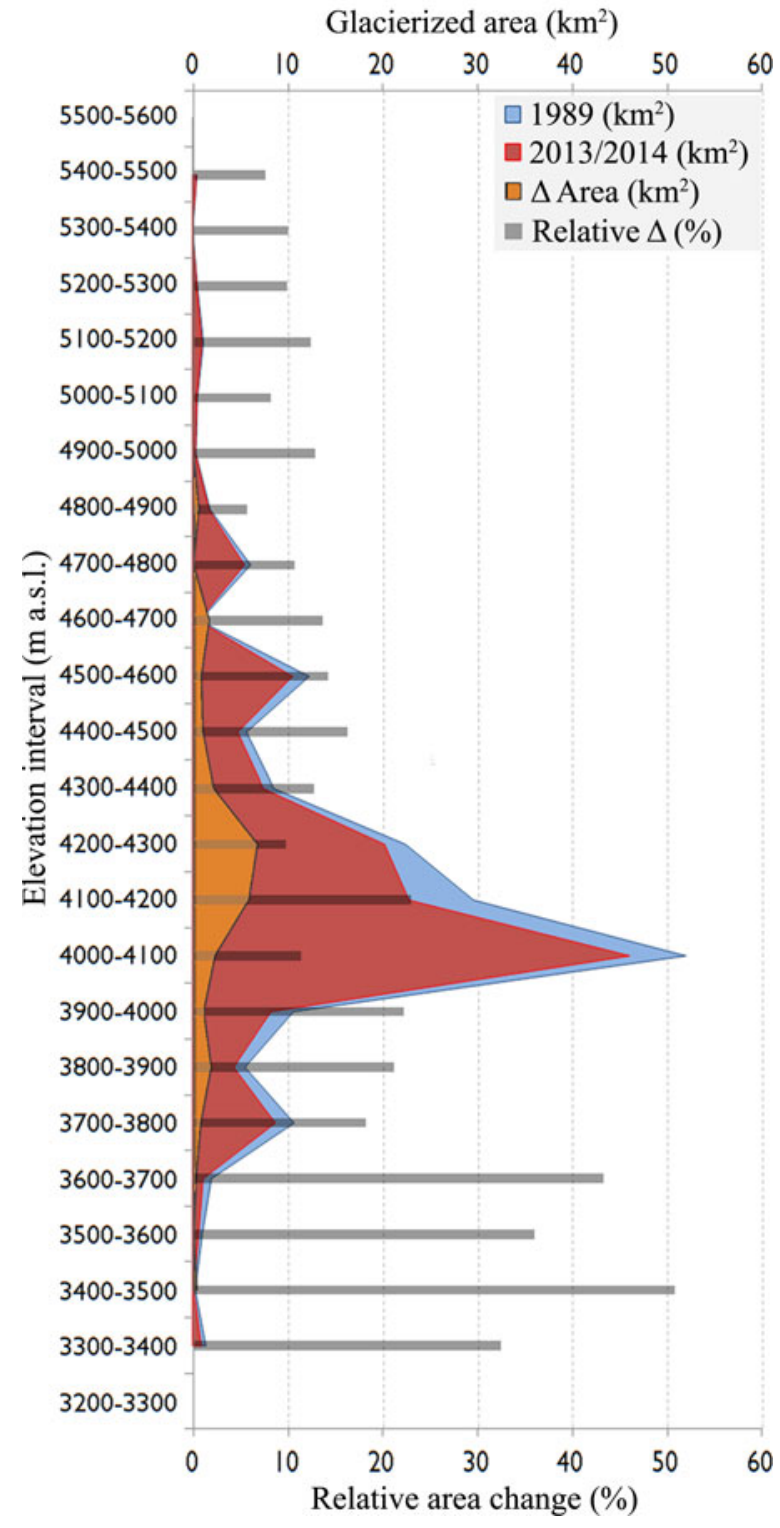

Fig. 2. Glacier area distribution and changes within 100 m elevation intervals between the 1989 and 2013/14 inventories, and relative area change between the inventories in \% (bars).

Hycon imagery to $\sim 8 \%$ for the outlines derived from the 1975 MSS image. Other potential uncertainties were related to the interpretation and manual digitization of the glacier margins. The manual mapping of glaciers from remotely sensed imagery is often hindered by the occurrence of topographic shadowing, seasonal snow cover and supraglacial debris (e.g. Dozier and Marks, 1987; Sandmeier and Itten, 1997; Paul and Andreassen, 2009; Paul and others, 2013). Areas of supraglacial debris are particularly difficult to identify from multi-spectral/panchromatic imagery due to the spectral similarities of the surrounding non-glacierized areas.

Image quality and pixel resolutions represent further challenges when delineating glaciers from satellite images. Coarser image resolutions, for example, often limit the ability to delineate terrain features precisely and increase the likelihood of mixed pixels containing a range of reflective signals (e.g. from supraglacial ice, snow and rocks). In this respect, the delineation of the upper boundaries of glaciers is often difficult due to varying amounts of snow cover 
between seasons. To limit the effect of this uncertainty, the 1989 glacier inventory (with minimal seasonal snow cover) was used as a delineation reference source for all other observation years. Other studies have applied similar error reduction methods (e.g. Paul and Andreassen, 2009; Paul and Molg, 2014). Glacier length change uncertainties for the subsample glaciers were calculated in relation to source image resolution and image co-registration errors (Williams and others, 1997; Hall and others, 2003).

\subsection{The 1955, 1989 and 2013/14 glacier inventories}

The 1955 inventory by Marangunic (1979) was produced from black-and-white aerial imagery, which is characterized by several seasonal snow patches. To improve comparability with the 1989 and 2013/14 inventories, the majority of the original 1955 glacier outlines and glacier divides needed modification and in some cases were disregarded all together when deemed unreliable. This often happened when snow had mistakenly been mapped, or poor georegistering played a role. Manually delineated outlines for the 1989 glacier inventory were produced from two Landsat 5 TM scenes $(30 \mathrm{~m})$ of approximately the same date $(3,17$ March). Outlines for the 2013/14 glacier inventory were delineated from four geo-referenced, very high spatial resolution GeoEye-1 scenes acquired in late March 2013 and a pansharpened Landsat 8 scene from February 2014. The three inventories include planimetric area, hypsometry and aspect information (Tables 1, 2). However, due to differences between the quality of the glacier delineation source data (as discussed above), separate glacier inventory analyses were conducted. The first analysis compared corresponding glacier areas present in the 1955, 1989 and 2013/14 inventories, hereafter referred to as the 1955 sample. The second analysis compared the larger glacier sample included in the 1989 and 2013/14 inventories.

\subsection{Glacier subsample 1955-2013}

In order to improve our understanding of glacier changes and hypsometry variations in the study area, we selected six major glaciers and analyzed them at a higher-temporal resolution. The selected glaciers included: Juncal Sur, Olivares Alfa, Olivares Gamma, Olivares Beta, Juncal Norte and Esmeralda (Fig. 1c). We analyzed glacier area, length change and elevation characteristics at 3-12 year intervals depending on image quality and availability. A total of 11 glacier observations, covering the years: 1955, 1967, 1975, 1985, 1989, 1994, 2000, 2002, 2008, 2010 and 2013 were chosen. These six glaciers; out of which five are the largest glaciers in the Rio Olivares basin (accounting for 2/ 3 of the basin glacier area in 2013/14), are all located within a radius of $\sim 20 \mathrm{~km}$ (denoted by red dots, Fig. 1). All together, these six glaciers covered an area of $58.5 \mathrm{~km}^{2}$ (in $2013 / 14$ ), accounting for $\sim 40 \%$ of the $144.3 \mathrm{~km}^{2}$ glacier area in the 2013/14 inventory. A mapping example of glacier Olivares Alfa can be seen in Fig. 3.

\section{RESULTS AND DISCUSSION}

\subsection{5, 1989 and 2013/14 inventories comparison}

The comparisons between the three inventories indicate widespread glacier recession. The combined glacier area (1955 sample) reduced by $40.3 \mathrm{~km}^{2} \quad\left(0.69 \mathrm{~km}^{2} \mathrm{a}^{-1}\right)$ between 1955 and 2013/14, a relative loss of 30\% $\left(0.5 \% \mathrm{a}^{-1}\right)$ (Table 1). The majority of this area loss occurred between 1955 and 1989, while the 1989-2013/14 period, showed slightly higher, but insignificant, relative glacier area loss $\left(0.68 \mathrm{~km}^{2} \mathrm{a}^{-1}, 0.5 \% \mathrm{a}^{-1}\right)$ compared with the initial period (1955-1989: $0.71 \mathrm{~km}^{2} \mathrm{a}^{-1}, 0.6 \% \mathrm{a}^{-1}$ ). From 1955-2013/ 14 , the mean glacier size decreased by $64 \%$, as a result of the widespread glacier disintegration. Through the whole period, the number of smaller glaciers increased, whilst the largest area was lost on larger glaciers (Fig. 4a). A scatter plot of the relative area changes plotted against the initial

Table 1. Area change comparisons between the 1955, 1989 and 2013/14 inventories

\begin{tabular}{|c|c|c|c|c|c|c|c|c|c|}
\hline \multirow[t]{2}{*}{ Date } & \multicolumn{2}{|c|}{ Area } & \multicolumn{2}{|c|}{ Mean size } & \multirow{2}{*}{$\begin{array}{c}\Delta \\
\mathrm{km}^{2}\end{array}$} & \multirow{2}{*}{$\begin{array}{c}\sigma \pm \\
\mathrm{km}^{2}\end{array}$} & \multirow{2}{*}{$\begin{array}{c}\Delta \\
\mathrm{km}^{2} \mathrm{a}^{-1}\end{array}$} & \multirow{2}{*}{$\begin{array}{l}\Delta \\
\%\end{array}$} & \multirow{2}{*}{$\begin{array}{c}\Delta \\
\% \mathrm{a}^{-1}\end{array}$} \\
\hline & $\mathrm{km}^{2}$ & $\sigma \pm \mathrm{km}^{2}$ & $\mathrm{~km}^{2}$ & Count & & & & & \\
\hline 24 February 1955 & 133.81 & 2.60 & 1.91 & 70 & & & & & \\
\hline 2 March 1989 & 110.59 & 16.37 & 1.19 & 94 & -23.22 & 3.55 & -0.68 & -17.4 & -0.5 \\
\hline 27 March 2013 & 89.24 & 1.92 & 0.80 & 110 & & & & & \\
\hline 10 February 2014 & 4.26 & 0.86 & 0.18 & 26 & & & & & \\
\hline$\Delta$ Total & & & & & -40.31 & & -0.69 & -30.1 & -0.5 \\
\hline
\end{tabular}

Table 2. Area change comparisons between the 1989 and 2013/14 larger sample inventories

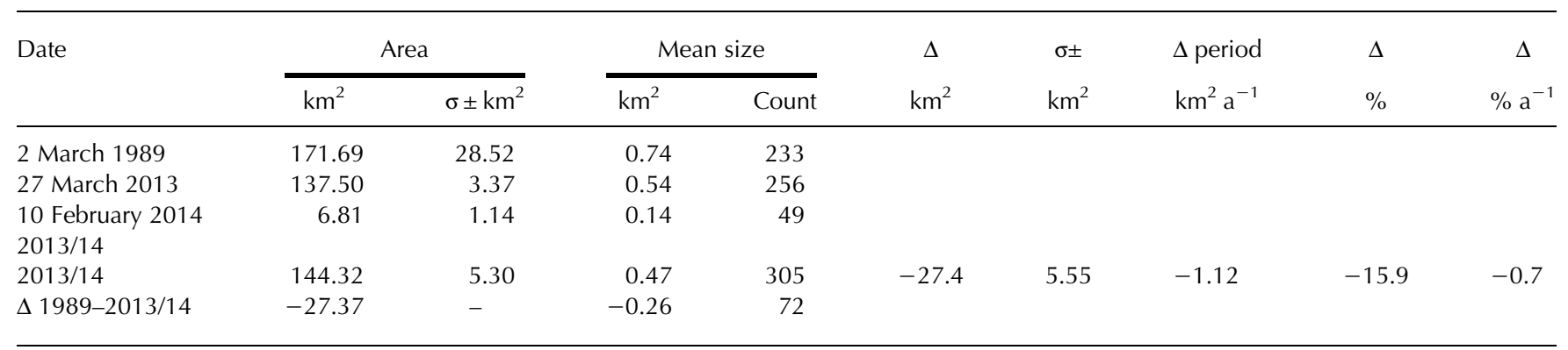




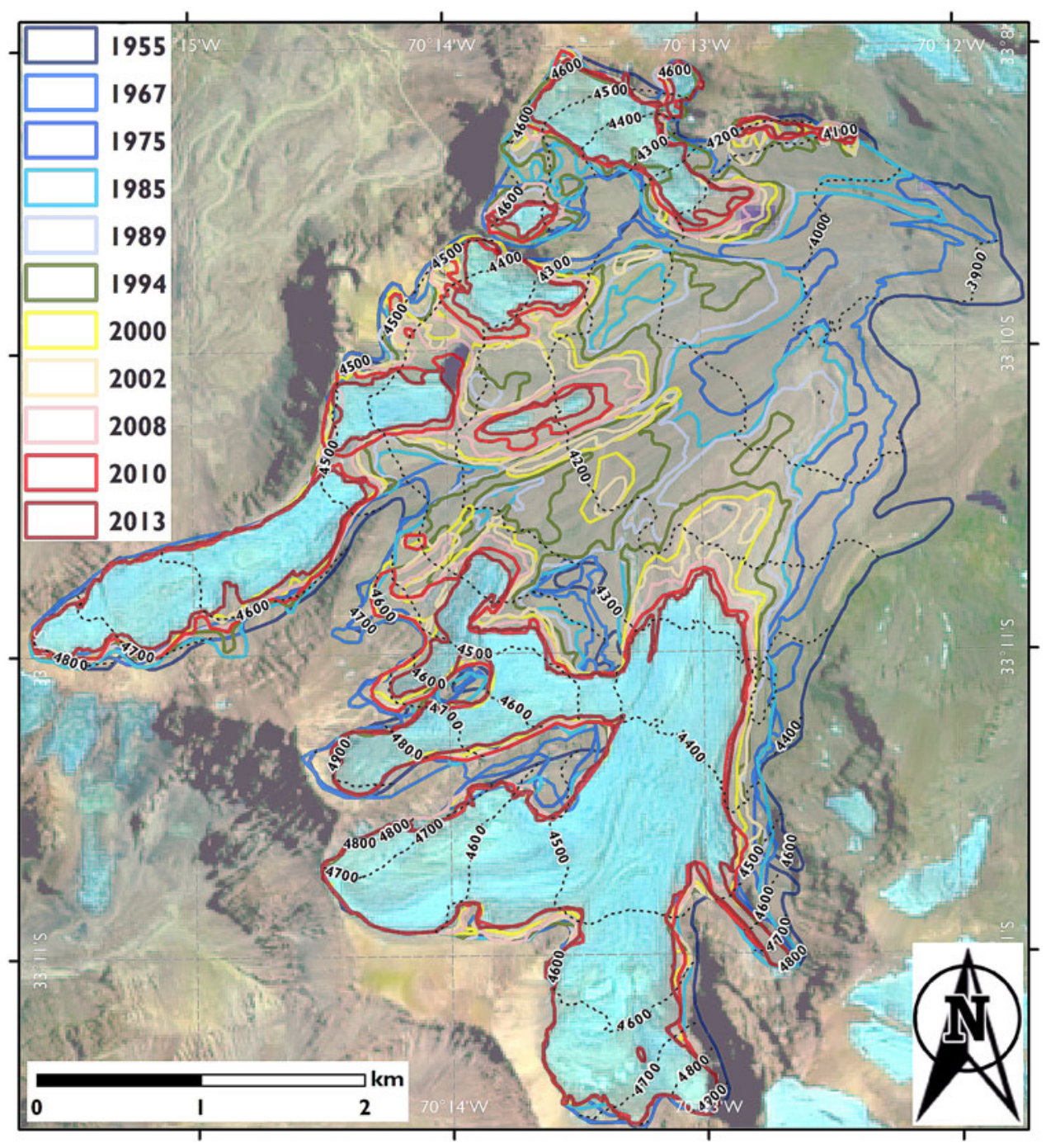

Fig. 3. Glacier extents for the Olivares Alfa glacier complex 1955-2013. The glacier has split up into several smaller segments and lost $63 \%$ of its ice area (image: 2014 Landsat 8 false color composite).

area (Fig. 5) shows higher variability for the smaller glaciers relative to the larger glaciers, a trend that becomes more prominent throughout the whole period. Similar scatter distributions have also been observed in the neighboring Aconcagua and Huasco basins to the north (Nicholson and others, 2009), and in the Chilean Lake district to the south (Paul and Molg, 2014). This distribution of glaciers is not surprising, since smaller glaciers are found over a wider range of locations, especially at high elevation where ice patches can form on steep mountain slopes, while larger glaciers tend to have large parts at lower elevations where surface temperatures are higher. The scatter plot also reveals that only four glaciers gained area from 1955 to 1989 and that during the last period, 1989-2013/14, these glaciers had lost all area gained in the preceding period.

The majority of the glaciers and ice areas sampled in this study were concentrated on south and southeast facing slopes, where the largest area losses occurred during the study period (Fig. 4b). Interestingly, western and northwestern facing glaciers were shown to increase in area (1955-2013/14), while glaciers having other aspects lost, on average, $17-88 \%$.

As a result of the area losses shown, mean glacier front elevations increased by an average of 108 m between 1955 and
1989, 138 m between 1989 and 2013/14 (totalling 246 m from 1955 to 2013/14). This frontal position behavior closely matches the estimated elevation change of the $0^{\circ} \mathrm{C}$ isotherm of $\sim 200 \mathrm{~m}$ in summer from 1975 to 2006 reported by Carrasco and others (2005).

The increase in area of western facing glaciers shown here could be the result of increased snowfall on western slopes and that these relatively small glaciers are found at high elevations (cold glaciers). It is, however, difficult to assess the importance of these changes since large glacier surfaces are characterized by a variation in aspect angles, and glaciers splitting from the main bodies thus end up with their own individual aspect alignments. We therefore suspect that, to some extent, the variability in glacier aspects is a result of glacier thinning and retreat.

\subsection{Comparison between the 1989 and $2013 / 14$ inventories}

The full 1989 and 2013/14 inventories include a much larger number of small glaciers than the 1955 sample, including a total of 233 individual glaciers in 1989 and 302 individual glaciers in 2013/14. 


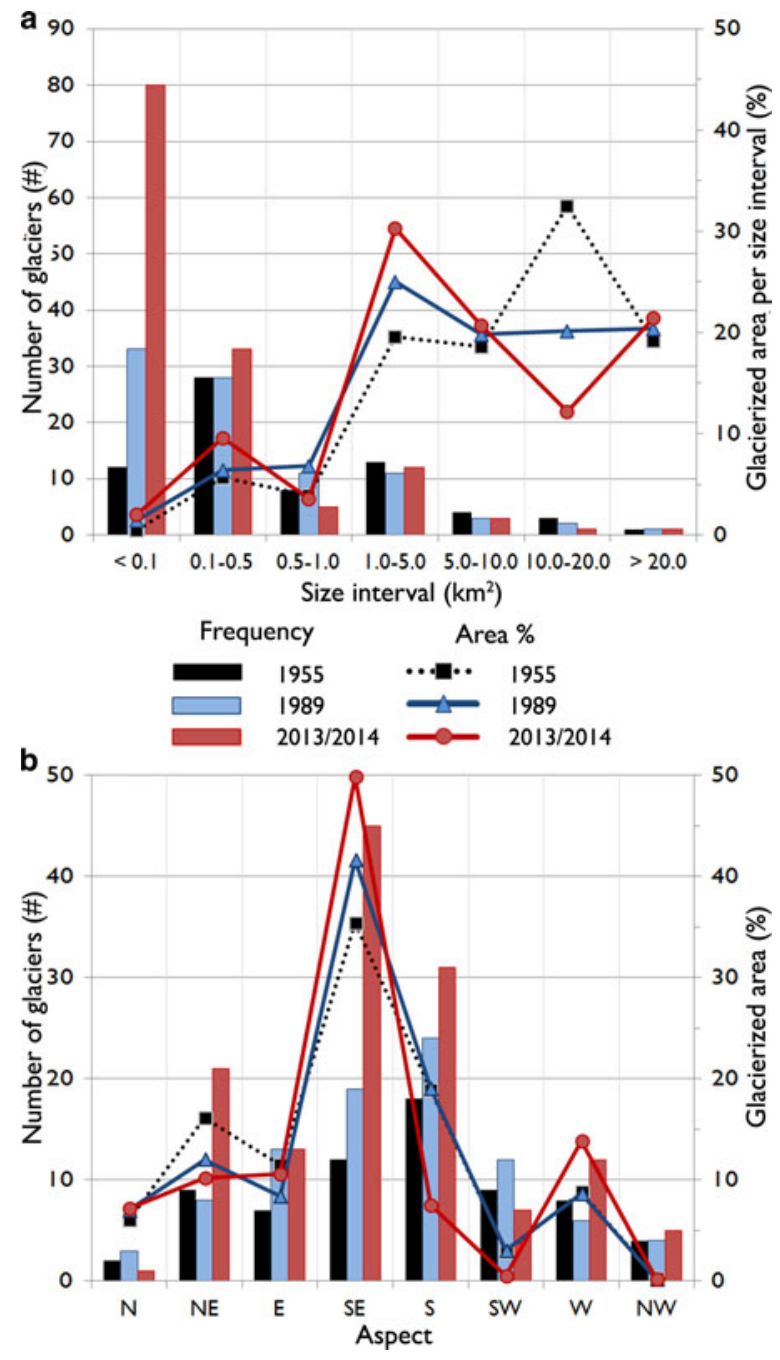

Fig. 4. (a) Glacier size intervals in relation to number of glaciers (bars) and area cover percentage (lines). (b) Glacier distribution, in regard to aspect, for glaciers present in all inventories $(1955,1989$ and 2013/14).

Between 1989 and 2013/14 glacier area reduced by 27.4 $\mathrm{km}^{2}(-16 \%)$, from $171.7 \mathrm{~km}^{2}$ in 1989 to $144.3 \mathrm{~km}^{2}$ in $2013 /$ 14 , with a mean area change rate of $-1.1 \mathrm{~km}^{2} \mathrm{a}^{-1}(-0.7 \%$ $\mathrm{a}^{-1}$ ) over the $24 / 25 \mathrm{a}$. The majority of the area loss for this period was identified for glaciers with mean elevations between 4000 and 4400 m a.s.l. (Fig. 2, bars). Not surprisingly, relative area changes for the glaciers in this study showed an inverse relationship with elevation. On average glaciers with mean elevations below $3600 \mathrm{~m}$ a.s.l. showed area loss of $>30 \%$ between 1989 and 2013/14 and glaciers with mean elevations above $5200 \mathrm{~m}$ a.s.l. showed area losses of $<10 \%$.

Throughout the observation period mean glacier size decreased by $37 \%$, from $0.74 \mathrm{~km}^{2}$ in 1989 to $0.48 \mathrm{~km}^{2}$ in 2013/14, similar to that observed for the 1955 sample. The number and total area of glaciers per size interval is plotted on Fig. $4 \mathrm{a}$, showing that glaciers in the $<0.1$ and $0.1-0.5 \mathrm{~km}^{2}$ intervals contain the highest number of glaciers, accounting for $79 \%$ (1989) and 88\% (2013/14) of the combined glacier samples, respectively. Over the observation period, the number of individual glaciers in these two intervals increased from 183 to 265 . However, the area contained within these intervals constitutes only 13 and $17 \%$ of the total glacierized area in 1989 and 2013/14, respectively

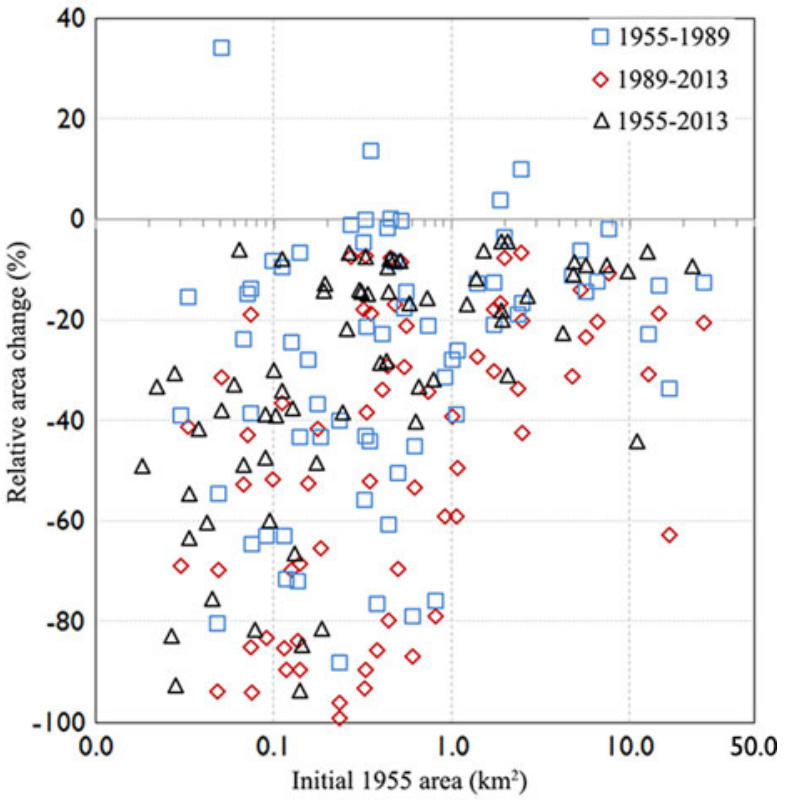

Fig. 5. Relative glacier area changes in \% from 1955 to 1989 , 19892013 and 1955-2013.

(Fig. 4b). In contrast, the $1-5 \mathrm{~km}^{2}$ interval contained the largest glacier areas, including 26 and $27 \%$ in 1989 and 2013/14, respectively. In 2013/14, Juncal Sur (>20 km²) and Olivares Gamma $\left(10-20 \mathrm{~km}^{2}\right)$ were the only two glaciers left in these intervals.

\subsection{Glacier subsample}

All the six subsample glaciers experienced area loss during the 58 a observation period, but at varying rates. Together, these six glaciers accounted for $63 \%$ or $25.2 \mathrm{~km}^{2}$ of the total area loss shown for the 1955-2013/14 sample (40.3 $\mathrm{km}^{2}$ ). As a result, these glaciers constitute the most important contributors to glacier area loss in the study area. To some extent, these individual glacier variations are comparable with previous glacier monitoring studies (Table 3).

The largest glacier in the study area, Juncal Sur, showed the second largest absolute area loss of $5.3 \mathrm{~km}^{2}$, corresponding to $21 \%$ of its 1955 area (Figs 6a, b; Table 4). In terms of relative area change, this is comparable with the Olivares Gamma and Esmeralda glaciers, which reduced by $21 \%$ $\left(3 \mathrm{~km}^{2}, 0.4 \% \mathrm{a}^{-1}\right)$ and $20 \%\left(1.4 \mathrm{~km}^{2}, 0.3 \% \mathrm{a}^{-1}\right)$, respectively. Area changes for Olivares Beta Glacier showed a similar pattern as the above mentioned glaciers only after the initial 1955-1967 period, when substantial area reductions took place. Overall, the Olivares Beta Glacier lost $4.3 \mathrm{~km}^{2}$ or $34 \%\left(0.6 \% \mathrm{a}^{-1}\right)$ of its 1955 area during the 58 years. A second distinct pattern can be seen at the Juncal Norte Glacier, which reduced by only $11 \%\left(0.8 \mathrm{~km}^{2}, 0.2 \% \mathrm{a}^{-1}\right)$ since 1955. Echaurren Norte, unlike the above, showed only minor area reduction before the 1990s, after which it mirrors the patterns of the other glaciers. A period of growth or stagnation between 2000 and 2008 was observed on all above mentioned glaciers. However, at the end of the time series 2008-2013 all these glaciers initiated a strong recession indicating a symmetry in response time. A third distinct pattern is observed for the Olivares Alfa Glacier. This glacier reduced by $63 \%\left(-10.5 \mathrm{~km}^{2},-1.1 \% \mathrm{a}^{-1}\right)$ in area between 1955 and 2013. This is in both relative and absolute 
Table 3. Comparison between the glacier change results presented in this study and in previous studies

\begin{tabular}{|c|c|c|c|c|c|c|c|c|}
\hline Glacier & $\begin{array}{c}1955 \text { Area } \\
\mathrm{km}^{2}\end{array}$ & $\begin{array}{l}\text { Study } \\
\text { period } \\
\text { Year }\end{array}$ & $\begin{array}{c}\text { Area } \\
\text { change } \\
\mathrm{km}^{2}\end{array}$ & $\begin{array}{c}\text { Area } \\
\text { change } \\
\%\end{array}$ & $\begin{array}{c}\text { Area } \\
\text { change rate } \\
\% \mathrm{a}^{-1}\end{array}$ & $\begin{array}{c}\text { Length } \\
\text { change } \\
M\end{array}$ & $\begin{array}{c}\text { Length } \\
\text { change rate } \\
\mathrm{m} \mathrm{a}^{-1}\end{array}$ & Source \\
\hline Juncal & 25.6 & 1955-1997 & -2.8 & -10.9 & -0.3 & -2108 & -50 & Rivera and others (2002) \\
\hline Sur & 25.8 & 1955-1994 & -3.7 & -14.3 & -0.4 & -2734 & -70 & This study \\
\hline Olivares & 14.7 & 1955-1997 & -0.4 & & & & & Rivera and others (2000) \\
\hline Gamma & & 1955-1997 & -1.2 & -8.2 & -0.2 & -623 & -15 & Rivera and others (2002) \\
\hline Olivares & & 1955-1979 & & & & -1000 & -42 & Lliboutry (1998) \\
\hline \multirow[t]{3}{*}{ Beta } & & $\begin{array}{l}1955-1997 \\
1955-1994\end{array}$ & -1.2 & & & -898 & -21 & $\begin{array}{l}\text { Rivera and others (2002) } \\
\text { Rivera and others (2000) }\end{array}$ \\
\hline & 12.5 & 1955-1975 & & & & -575 & -29 & This study \\
\hline & & 1955-1994 & -3.7 & -29.8 & -0.8 & -753 & -19 & This study \\
\hline Juncal & 9.0 & 1955-1997 & -0.2 & 2.4 & -0.1 & -170 & -4 & Rivera and others (2002) \\
\hline \multirow[t]{9}{*}{ Norte } & & 1997-2000 & & & & -12 & -4 & Rivera and others (2002) \\
\hline & & 1989-1997 & -1.0 & -11.1 & -1.4 & -185 & -23 & Bown and others (2008) \\
\hline & & 1997-1999 & 0.0 & -0.3 & -0.2 & -40 & -20 & Bown and others (2008) \\
\hline & & 1999-2006 & -0.4 & -3.9 & -0.6 & -119 & -17 & Bown and others (2008) \\
\hline & & 1955-2006 & -1.5 & -16.2 & -0.3 & -464 & -9 & Bown and others (2008) \\
\hline & 7.5 & 1955-1994 & -0.3 & -3.5 & -0.1 & -212 & -5 & This study \\
\hline & & 1994-2000 & -0.3 & -4.1 & -0.7 & -197 & -33 & This study \\
\hline & & 2000-2008 & -0.2 & -2.1 & -0.3 & -260 & -33 & This study \\
\hline & & 1955-2008 & -0.4 & -5.6 & -0.1 & -472 & -9 & This study \\
\hline
\end{tabular}
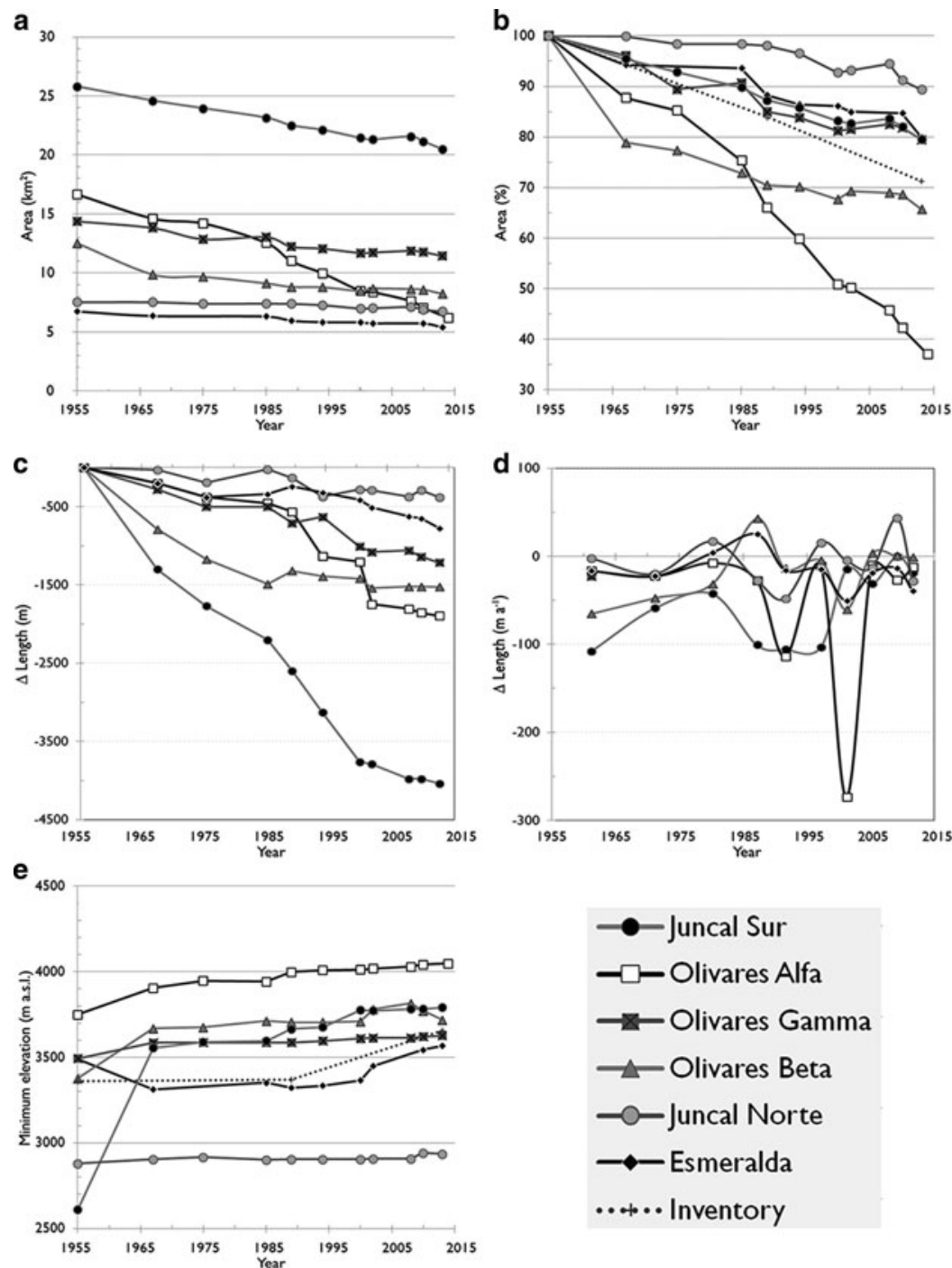

Fig. 6. Area and length change for the glacier subsample between 1955 and 2013/2014: (a) Glacier area changes (km²). (b) Relative glacier area changes (\%). (c) Glacier length changes. (d) Glacier length fluctuations $\left(\mathrm{m} \mathrm{a}^{-1}\right)$. (e) Front elevation variations (m). 
Table 4. Observed area (including uncertainty), elevation and length from 1955 to 2013 for the subsample glaciers. Relative area and length changes (\%) for each glacier are also shown

\begin{tabular}{|c|c|c|c|c|c|c|c|c|c|c|c|c|}
\hline \multirow[t]{2}{*}{ Date } & \multirow[t]{2}{*}{ Area } & \multirow{2}{*}{$\begin{array}{l}\text { Area } \\
\sigma \pm\end{array}$} & \multicolumn{3}{|c|}{ Elevation } & \multirow{2}{*}{$\begin{array}{l}\text { Slope } \\
\text { Mean }\end{array}$} & \multirow{2}{*}{$\begin{array}{c}\Delta \\
\text { length }\end{array}$} & \multirow{2}{*}{$\begin{array}{l}\text { Length } \\
\Delta \mathrm{a}^{-1}\end{array}$} & \multirow{2}{*}{$\begin{array}{c}\text { Area } \\
\Delta\end{array}$} & \multirow{2}{*}{$\begin{array}{l}\text { Area } \\
\Delta \mathrm{a}^{-1}\end{array}$} & \multirow{2}{*}{$\begin{array}{l}\text { Area } \\
\sum(\Delta)\end{array}$} & Area \\
\hline & & & Min & Max & mean & & & & & & & $\sum(\Delta) \%$ \\
\hline Juncal & -70.12 & $33.10^{\circ} \mathrm{S}$ & & & & & & & & & & \\
\hline Sur & $\mathrm{km}^{2}$ & & $\mathrm{~m}$ a.s.l. & & & deg & $\mathrm{m}$ & $\mathrm{ma}^{-1}$ & $\mathrm{~km}^{2}$ & & & $\%$ \\
\hline 24 February 1955 & 25.8 & 0.3 & 2608 & 5860 & 3809 & 15.8 & - & - & - & - & - & - \\
\hline 5 March 1967 & 24.6 & 0.3 & 3555 & 5695 & 4333 & 16.0 & -887 & -73.8 & -1.19 & -0.10 & -1.19 & 4.6 \\
\hline 14 February 1975 & 24.0 & 4.2 & 3589 & 5718 & 4363 & 16.2 & -403 & -50.7 & -0.65 & -0.08 & -1.84 & 7.1 \\
\hline 14 March 1985 & 23.2 & 1.8 & 3595 & 5695 & 4364 & 16.1 & -446 & -44.3 & -0.80 & -0.08 & -2.64 & 10.2 \\
\hline 2 March 1989 & 22.5 & 2.0 & 3665 & 5695 & 4364 & 16.1 & -305 & -76.9 & -0.65 & -0.16 & -3.29 & 12.8 \\
\hline 27 February 1994 & 22.1 & 1.9 & 3675 & 5713 & 4373 & 16.2 & -693 & -138.8 & -0.39 & -0.08 & -3.68 & 14.3 \\
\hline 31 March 2000 & 21.5 & 0.9 & 3775 & 5695 & 4380 & 16.0 & -610 & -100.2 & -0.67 & -0.11 & -4.35 & 16.9 \\
\hline 21 March 2002 & 21.3 & 0.9 & 3772 & 5695 & 4382 & 16.4 & -81 & -41.1 & -0.13 & -0.07 & -4.48 & 17.4 \\
\hline 30 March 2008 & 21.6 & 0.9 & 3782 & 5695 & 4386 & 16.8 & -136 & -22.6 & 0.24 & 0.04 & -4.24 & 16.4 \\
\hline 30 January 2010 & 21.2 & 1.0 & 3782 & 5713 & 4385 & 16.4 & 0 & 0.0 & -0.41 & -0.22 & -4.65 & 18.0 \\
\hline 27 March 2013 & 20.5 & 1.0 & 3791 & 5718 & 4385 & 16.8 & -223 & -70.7 & -0.65 & -0.21 & -5.30 & 20.5 \\
\hline Total & -5.3 & & 1183 & -142 & 576 & 1.0 & -3784 & & -5.30 & & -5.30 & -20.5 \\
\hline Mean & & 1.4 & & & & & & -61.9 & & -0.11 & - & \\
\hline Olivares & -70.22 & $33.19^{\circ} \mathrm{S}$ & & & & & & & & & & \\
\hline Alfa & $\mathrm{km}^{2}$ & & $\mathrm{~m}$ a.s.l. & & & deg & $\mathrm{m}$ & $\mathrm{m} \mathrm{a}^{-1}$ & $\mathrm{~km}^{2}$ & & & $\%$ \\
\hline 24 February 1955 & 16.6 & 0.2 & 3750 & 5120 & 4438 & 15.0 & - & - & - & - & - & - \\
\hline 5 March 1967 & 14.6 & 0.2 & 3906 & 4987 & 4357 & 15.7 & -250 & -20.8 & -2.04 & -0.17 & -2.04 & 12.3 \\
\hline 14 February 1975 & 14.2 & 3.3 & 3947 & 4996 & 4386 & 15.8 & -150 & -18.9 & -0.41 & -0.05 & -2.45 & 14.7 \\
\hline 14 March 1985 & 12.6 & 1.5 & 3942 & 4943 & 4392 & 15.5 & -125 & -12.4 & -1.64 & -0.16 & -4.09 & 24.6 \\
\hline 2 March 1989 & 11.0 & 1.6 & 3999 & 4943 & 4410 & 15.3 & -76 & -19.2 & -1.56 & -0.39 & -5.65 & 34.0 \\
\hline 27 February 1994 & 10.0 & 1.7 & 4010 & 4933 & 4440 & 15.5 & -706 & -141.4 & -1.03 & -0.21 & -6.68 & 40.1 \\
\hline 31 March 2000 & 8.5 & 0.8 & 4013 & 4933 & 4464 & 15.0 & -165 & -27.1 & -1.49 & -0.24 & -8.17 & 49.1 \\
\hline 21 March 2002 & 8.4 & 0.8 & 4019 & 4943 & 4477 & 15.4 & -93 & -47.2 & -0.11 & -0.06 & -8.28 & 49.8 \\
\hline 30 March 2008 & 7.6 & 0.7 & 4030 & 4933 & 4492 & 15.9 & -387 & -64.2 & -0.74 & -0.12 & -9.02 & 54.2 \\
\hline 30 January 2010 & 7.0 & 0.7 & 4043 & 4943 & 4505 & 15.1 & -76 & -41.4 & -0.58 & -0.32 & -9.60 & 57.7 \\
\hline 27 March 2013 & 6.2 & 0.7 & 4048 & 4933 & 4514 & 15.9 & -25 & -7.9 & -0.87 & -0.28 & -10.47 & 62.9 \\
\hline Total & -10.5 & & 298 & -187 & 76 & 0.9 & -2053 & & -10.47 & & -10.47 & -62.9 \\
\hline Mean & & 1.1 & & & & & & -40.0 & & -0.20 & - & \\
\hline Olivares & -70.1 & $.12^{\circ} \mathrm{S}$ & & & & & & & & & & \\
\hline Gamma & $\mathrm{km}^{2}$ & & $\mathrm{~m}$ a.s.l. & & & deg & $\mathrm{m}$ & $\mathrm{m} \mathrm{a}^{-1}$ & $\mathrm{~km}^{2}$ & & & $\%$ \\
\hline 24 February 1955 & 14.4 & 0.1 & 3492 & 4981 & 4328 & 15.8 & - & - & - & - & - & - \\
\hline 5 March 1967 & 13.8 & 0.2 & 3585 & 4966 & 4350 & 15.9 & -403 & -33.5 & -0.57 & -0.05 & -0.57 & 4.0 \\
\hline 14 February 1975 & 12.9 & 2.2 & 3587 & 4981 & 4380 & 15.9 & -249 & -31.3 & -0.95 & -0.12 & -1.52 & 10.6 \\
\hline 14 March 1985 & 13.0 & 1.0 & 3587 & 4981 & 4380 & 15.9 & -138 & -13.7 & 0.18 & 0.02 & -1.34 & 9.3 \\
\hline 2 March 1989 & 12.2 & 1.0 & 3587 & 4981 & 4390 & 15.8 & -74 & -18.7 & -0.82 & -0.21 & -2.16 & 15.0 \\
\hline 27 February 1994 & 12.1 & 1.0 & 3596 & 4953 & 4395 & 15.9 & -115 & -23.0 & -0.17 & -0.03 & -2.33 & 16.2 \\
\hline 31 March 2000 & 11.7 & 0.5 & 3609 & 4950 & 4401 & 15.8 & -115 & -18.9 & -0.37 & -0.06 & -2.70 & 18.8 \\
\hline 21 March 2002 & 11.7 & 0.5 & 3613 & 4963 & 4403 & 16.6 & -50 & -25.4 & 0.05 & 0.03 & -2.65 & 18.4 \\
\hline 30 March 2008 & 11.9 & 0.5 & 3613 & 4981 & 4404 & 16.1 & -70 & -11.6 & 0.14 & 0.02 & -2.51 & 17.5 \\
\hline 30 January 2010 & 11.8 & 0.5 & 3620 & 4966 & 4410 & 16.5 & 0 & 0.0 & -0.11 & -0.06 & -2.62 & 18.2 \\
\hline 27 March 2013 & 11.4 & 0.5 & 3627 & 4981 & 4411 & 16.3 & -50 & -15.9 & -0.33 & -0.10 & -2.95 & 20.5 \\
\hline Total & -2.3 & & 135 & 0 & 83 & 0.5 & -1264 & & -2.95 & & -2.95 & -20.5 \\
\hline Mean & & 0.7 & & & & & & -19.2 & & -0.06 & - & \\
\hline Olivares & -70.20 & $33.14^{\circ} \mathrm{S}$ & & & & & & & & & & \\
\hline Beta & $\mathrm{km}^{2}$ & & m a.s.l. & & & deg & $\mathrm{m}$ & $\mathrm{ma}^{-1}$ & $\mathrm{~km}^{2}$ & & & $\%$ \\
\hline 24 February 1955 & 12.5 & 0.2 & 3376 & 4900 & 4143 & 14.0 & - & - & - & - & - & - \\
\hline 5 March 1967 & 9.9 & 0.1 & 3669 & 4899 & 4466 & 13.9 & -275 & -22.9 & -2.64 & -0.22 & -2.64 & 21.1 \\
\hline 14 February 1975 & 9.7 & 2.0 & 3675 & 4899 & 4486 & 13.9 & -300 & -37.7 & -0.20 & -0.03 & -2.84 & 22.7 \\
\hline 14 March 1985 & 9.1 & 0.8 & 3712 & 4899 & 4490 & 14.0 & -283 & -28.1 & -0.55 & -0.05 & -3.39 & 27.1 \\
\hline 2 March 1989 & 8.8 & 0.8 & 3705 & 4899 & 4488 & 14.0 & 71 & 17.9 & -0.31 & -0.08 & -3.70 & 29.6 \\
\hline 27 February 1994 & 8.8 & 0.8 & 3705 & 4899 & 4487 & 14.1 & 34 & 6.8 & -0.03 & -0.01 & -3.73 & 29.8 \\
\hline 31 March 2000 & 8.5 & 0.4 & 3710 & 4899 & 4492 & 14.1 & -30 & -4.9 & -0.31 & -0.05 & -4.04 & 32.3 \\
\hline 21 March 2002 & 8.7 & 0.4 & 3780 & 4899 & 4490 & 14.0 & -40 & -20.3 & 0.20 & 0.10 & -3.84 & 30.7 \\
\hline 30 March 2008 & 8.6 & 0.4 & 3815 & 4899 & 4491 & 14.2 & -40 & -6.6 & -0.04 & -0.01 & -3.88 & 31.0 \\
\hline 30 January 2010 & 8.6 & 0.4 & 3772 & 4899 & 4493 & 14.2 & -25 & -13.6 & -0.05 & -0.03 & -3.93 & 31.4 \\
\hline 27 March 2013 & 8.2 & 0.1 & 3719 & 4899 & 4493 & 15.6 & -47 & -14.9 & -0.36 & -0.11 & -4.29 & 34.3 \\
\hline Total & -4.3 & & 343 & -1 & 350 & 1.6 & -935 & & -4.29 & & -4.29 & -34.3 \\
\hline Mean & & 0.6 & & & & & & -12.4 & & -0.05 & - & \\
\hline Juncal & -70.10 & $33.03^{\circ} \mathrm{S}$ & & & & & & & & & & \\
\hline Norte & $\mathrm{km}^{2}$ & & m a.s.l. & & & deg & $\mathrm{m}$ & $\mathrm{ma}^{-1}$ & $\mathrm{~km}^{2}$ & & & $\%$ \\
\hline 24 February 1955 & 7.5 & 0.1 & 2878 & 5866 & 4611 & 26.6 & - & - & - & - & - & - \\
\hline 5 March 1967 & 7.5 & 0.1 & 2904 & 5866 & 4633 & 26.7 & -272 & -22.6 & 0.00 & 0.00 & 0.00 & 0.0 \\
\hline
\end{tabular}


Table 4. (Cont.)

\begin{tabular}{|c|c|c|c|c|c|c|c|c|c|c|c|c|}
\hline \multirow[t]{2}{*}{ Date } & \multirow[t]{2}{*}{ Area } & \multirow{2}{*}{$\begin{array}{l}\text { Area } \\
\sigma \pm\end{array}$} & \multicolumn{3}{|c|}{ Elevation } & \multirow{2}{*}{$\begin{array}{l}\text { Slope } \\
\text { Mean }\end{array}$} & \multirow{2}{*}{$\begin{array}{c}\Delta \\
\text { length }\end{array}$} & \multirow{2}{*}{$\begin{array}{l}\text { Length } \\
\Delta \mathrm{a}^{-1}\end{array}$} & \multirow{2}{*}{$\begin{array}{c}\text { Area } \\
\qquad \Delta\end{array}$} & \multirow{2}{*}{$\begin{array}{l}\text { Area } \\
\Delta \mathrm{a}^{-1}\end{array}$} & \multirow{2}{*}{$\begin{array}{l}\text { Area } \\
\sum(\Delta)\end{array}$} & \multirow{2}{*}{$\begin{array}{c}\text { Area } \\
\sum(\Delta) \%\end{array}$} \\
\hline & & & Min & Max & mean & & & & & & & \\
\hline 14 March 1985 & 7.4 & 0.8 & 2901 & 5866 & 4618 & 26.6 & 232 & 23.0 & 0.00 & 0.00 & 0.12 & 1.6 \\
\hline 2 March 1989 & 7.4 & 0.8 & 2903 & 5866 & 4608 & 26.5 & 140 & 35.3 & 0.02 & 0.01 & 0.14 & 1.9 \\
\hline 27 February 1994 & 7.3 & 0.8 & 2903 & 5866 & 4626 & 26.6 & -37 & -7.4 & 0.12 & 0.02 & 0.26 & 3.5 \\
\hline 21 March 2002 & 7.0 & 0.4 & 2906 & 5866 & 4647 & 26.7 & -50 & -25.4 & -0.04 & -0.02 & 0.51 & 6.8 \\
\hline 30 March 2008 & 7.1 & 0.4 & 2908 & 5866 & 4630 & 26.9 & -50 & -8.3 & -0.09 & -0.01 & 0.42 & 5.6 \\
\hline 30 January 2010 & 6.9 & 0.4 & 2941 & 5866 & 4661 & 27.0 & 0 & 0.0 & 0.24 & 0.13 & 0.66 & 8.8 \\
\hline 27 March 2013 & 6.7 & 0.1 & 2934 & 5866 & 4672 & 26.9 & 20 & 6.3 & 0.13 & 0.04 & 0.79 & 10.5 \\
\hline Total & -0.8 & & 56 & 0 & 61 & 0.3 & -452 & & 0.79 & & 0.79 & -10.5 \\
\hline Mean & & 0.5 & & & & & & -6.0 & & 0.02 & - & \\
\hline Esmeralda & $\begin{array}{l}-70.20 \\
\mathrm{~km}^{2}\end{array}$ & $33.22^{\circ} \mathrm{S}$ & $\mathrm{m}$ a.s.l. & & & deg & $\mathrm{m}$ & $\mathrm{m} \mathrm{a}^{-1}$ & $\mathrm{~km}^{2}$ & & & $\%$ \\
\hline 24 February 1955 & 6.7 & 0.1 & 3490 & 5545 & 4850 & 20.6 & - & - & - & - & - & - \\
\hline 5 March 1967 & 6.4 & 0.1 & 3312 & 5361 & 4851 & 20.9 & -160 & -13.3 & 0.38 & 0.03 & 0.38 & 5.6 \\
\hline 14 March 1985 & 6.3 & 0.8 & 3351 & 5366 & 4859 & 21.0 & -200 & -11.1 & 0.05 & 0.00 & 0.43 & 6.4 \\
\hline 2 March 1989 & 5.9 & 0.7 & 3321 & 5363 & 4866 & 21.1 & 100 & 25.2 & 0.36 & 0.09 & 0.79 & 11.7 \\
\hline 27 February 1994 & 5.8 & 0.7 & 3335 & 5356 & 4883 & 21.2 & -50 & -10.0 & 0.12 & 0.02 & 0.91 & 13.5 \\
\hline 31 March 2000 & 5.8 & 0.4 & 3365 & 5364 & 4886 & 21.3 & -95 & -15.6 & 0.02 & 0.00 & 0.93 & 13.8 \\
\hline 21 March 2002 & 5.7 & 0.4 & 3449 & 5363 & 4890 & 22.9 & -65 & -33.0 & 0.08 & 0.04 & 1.01 & 15.0 \\
\hline 30 January 2010 & 5.7 & 0.4 & 3544 & 5356 & 4898 & 21.7 & -97 & -12.3 & 0.02 & 0.00 & 1.03 & 15.3 \\
\hline 27 March 2013 & 5.4 & 0.1 & 3568 & 5364 & 4904 & 21.3 & -52 & -16.5 & 0.32 & 0.10 & 1.35 & 20.1 \\
\hline Total & 5.4 & & 3568 & 5364 & 54 & 21.3 & -619 & & 1.35 & & 1.35 & -20.1 \\
\hline Mean & & 0.4 & & & & & & -10.8 & & 0.04 & - & \\
\hline
\end{tabular}

area reduction, considerably larger than for the similarly sized glaciers described above and around twice that for the mean inventory glacier for the same period as seen in Fig. 6b. While Olivares Alfa shows continuous area loss throughout the period, between 1967 and 1975, and again between 2000 and 2008, the rate of reduction slowed down. This later period in turn coincides with the period of glacier growth for the five glaciers, showing a common pattern in response to changing climate conditions.

Variability in glacier length is often viewed upon as a natural indicator of past climate change and has, for example, been used to assess the effect of glacier changes on mountain hydrology (e.g. Shiyin and others, 2003; Leclercq and others, 2014). The pattern of glacier length changes for the six subsample glaciers, in many ways, resembles the pattern found in area changes. This is mainly due to the fact that glacier ablation under normal conditions is dominant at the lower elevation parts of a glacier, below the equilibrium line and especially near the front. When considering frontal changes for the subsample, Juncal Sur Glacier stands out (Fig. 6c). This glacier retreated by $3784 \mathrm{~m}$, the largest retreat of all the six glaciers, averaging $-62 \mathrm{~m} \mathrm{a}^{-1}$. Two periods of especially rapid rate of frontal retreat for Juncal Sur were observed for 1955-1967 and 1989-2000, the later period with $>100 \mathrm{~m} \mathrm{a}^{-1}$ (Fig. 6d). An interesting observation is that the only other glacier showing similar behavior is Olivares Alfa. Overall, glacier front positions for Olivares Alfa retreated $2053 \mathrm{~m}\left(-40 \mathrm{~m} \mathrm{a}^{-1}\right)$ between 1955 and 2013. The frontal retreat of Olivares Alfa peaked between 1989 and 2000, with a rate of $141 \mathrm{~m} \mathrm{a}^{-1}$, exceeding that observed for Juncal Sur between 2002 and 2010. A second pattern is identified for the Esmeralda, Olivares Beta and Juncal Norte glaciers, which retreated by $619 \mathrm{~m}(-11 \mathrm{~m}$

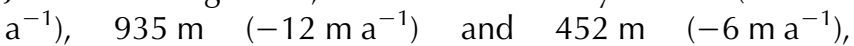

respectively. These three glaciers experienced periodic events of front advance between 1975 and 1989 and, for Juncal Norte, again between 2002 and 2010. A third pattern is found for Olivares Gamma, where the front retreated by $1264 \mathrm{~m}\left(-19 \mathrm{~m} \mathrm{a}^{-1}\right)$. Olivares Gamma, unlike the others, had a relatively stable front, showing continuous retreat without many fluctuations.

The retreat experienced by these six glaciers changed the elevation of the fronts but at very different rates. The front elevation for Juncal Sur increased by $1183 \mathrm{~m}$, and in 1955 the glacier was still retreating from its 1947 surge maximum. Front elevations for Olivares Alfa, Beta and Gamma glaciers changed more moderately by 298, 135 and 343 m, respectively, while the fronts of Juncal Norte and Esmeralda changed by 56 and $78 \mathrm{~m}$, respectively (Fig. 6e).

Higher frequencies of above average winter snow accumulation, observed since 1976 at the Echaurren Norte Glacier, $\sim 200 \mathrm{~km}$ south of the subsample glaciers, and high snow accumulation events from 1980 to 1985 (Masiokas and others, 2006), could have played a role in the evolution of these glaciers. During the period 19751989 some of the glaciers stabilized and Olivares Gamma showed a small area gain, while Juncal Sur and Olivares Beta and especially Alfa, showed substantial area loss. There are several possible causes that may explain Olivares Alfa's particularly dramatic ice area loss. One hypothesis is that Olivares Alfa is more sensitive to recent climate change compared with other glaciers in the area because it is polythermal in type (Gacitua and others, 2015). Alternatively, the increased climate sensitivity could be related to its location on eastern-facing leeward slopes, which may receive less precipitation. Another factor that may influence the climate sensitivity of both Olivares Alfa and Olivares Beta is the proximity to the Los Bronces open 
pit mine (opened in 1970). Deposition of mining related dust particles on the surface of these two glaciers could influence surface energy balances as shown, for example, on glaciers in the Alps (Oerlemans and others, 2009).

\section{CONCLUSION AND FUTURE PERSPECTIVES}

We compiled two new inventories from 1989 and 2013/14 and performed a reinterpretation of an existing inventory from 1955 covering an important glacierized area of the central Chilean and Argentinean Andes. Inventory comparisons revealed widespread glacier shrinkages of $30 \pm 3 \%$ $\left(0.5 \% \mathrm{a}^{-1}\right)$ from 1955 to $2013 / 14$. Due to the disintegration of medium and large sized glaciers, caused by thinning and frontal retreat, mean glacier size decreased by $64 \%$, while individual glacier numbers increased from 70 to 136 during the 58/59 year study period. Comparisons between the 1955, 1989 and 2013/14 inventories also revealed a small but insignificant increase in relative area loss rates. This comparison indicated a relatively constant trend in overall glacier area loss since 1955. During the study period, glacier minimum elevation increased by $108 \mathrm{~m}$ between 1955 and 1989, and a further $138 \mathrm{~m}$ from 1989 to 2013/14.

The detailed analysis of six major glaciers located in and around the Rio Olivares basin revealed varying rates and magnitudes of area change and frontal retreat. The Olivares Alfa Glacier particularly stood out during this analysis, having reduced in area by 63\% since 1955 .

Ongoing studies concerning mass balance and water resource potential have been initiated by the DGA on several glaciers in the area, including Olivares Alfa and Beta glaciers. A separate mass balance study is also ongoing on Olivares Gamma. We hope these studies in time will improve our understanding of glaciers in this region. Also, recent development in multispectral high-resolution image availability is expected to be of particular importance for the central Andes of Chile and Argentina, where many glacierized areas have not yet been sufficiently mapped.

\section{ACKNOWLEDGEMENTS}

This study was funded by the National Science Foundation of Chile FONDECYT under Grant Agreement \#1140172, and by Centro de Estudios Científicos (CECs), which is funded by the Chilean Government through the Centers of Excellence Base Financing Program of CONICYT. Satellite data used are available from the U.S. Geological Survey, distributed by the Land Processes Distributed Active Archive Center (LP DAAC), http://lpdaac.usgs.gov. GeoEye-1 scenes were acquired through DigitalGlobe (www.digitalglobe. com), as part of a glacier observation project funded by the Anglo American mining corporation. Applications for the glacier data should be directed to the first author. We thank the two anonymous reviewers for valuable comments and suggestions.

\section{REFERENCES}

Aniya M, Sato H, Naruse R, Skvarca P and Casassa G (1996) The use of satellite and airborne imagery to inventory outlet glaciers of the Southern Patagonia Icefield, South America. Photogramm. Eng. Remote Sens., 62(12), 1361-1369
Bown F, Rivera A and Acuña C (2008) Recent glacier variations at the Aconcagua basin, central Chilean Andes. Ann. Glaciol. 48(1), 43-48 (doi: 10.3189/172756408784700572)

Carrasco JF, Casassa G and Quintana J (2005) Changes of the 0 degrees $\mathrm{C}$ isotherm and the equilibrium line altitude in central Chile during the last quarter of the 20th century. Hydrolog. Sci. J., 50(6), 933-948 (doi: 10.1623/hysj.2005.50.6.933)

Davies BJ and Glasser NF (2012) Accelerating shrinkage of Patagonian glaciers from the Little Ice Age (similar to AD 1870) to 2011. J. Glaciol., 58(212), 1063-1084 (doi: 10.3189/2012JoG12J026)

Dozier J and Marks D (1987) Snow Mapping and classification from Landsat Thematic Mapper data. Ann. Glaciol., 9, 97-103

Escobar F, Casassa G and Pozo V (1995) Variaciones de un glaciar de Montaña en los Andes de Chile Central en las últimas dos décadas. BIFEA, 24(3), 683-995

Espizúa LE and Lydia E (1986) Fluctuations of the Rio del Plomo Glaciers. Geogr. Ann. A., 68(4), 317-327 (doi: 10.2307/521524)

Falaschi D, Bravo C, Masiokas M, Villalba R and Rivera A (2013) First glacier inventory and recent changes in glacier area in the monte san lorenzo region $\left(47^{\circ} \mathrm{S}\right)$, Southern Patagonian Andes, South America. Arct. Antarct. Alp. Res., 45(1), 19-28 (doi: 10.1657/1938-4246-45.1.19)

Falvey M and Garreaud RD (2009) Regional cooling in a warming world: recent temperature trends in the southeast Pacific and along the west coast of subtropical South America (19792006). J. Geophys. Res.-Atmos., 114, D04102 (doi: 10.1029/ 2008jd010519)

Favier V, Falvey M, Rabatel A, Praderio E and Lopez D (2009) Interpreting discrepancies between discharge and precipitation in high-altitude area of Chile's Norte Chico region (26-32 degrees S). Water. Resour. Res., 45, W02424 (doi: Artn W0242410.1029/2008wr006802)

Gacitua G, Uribe JA, Wilson R., Loriaux T, Hernandez J and Rivera A (2015) $50 \mathrm{MHz}$ helicopter-borne radar data for determination of glacier thermal regime in the central Chilean Andes. Ann. Glaciol., 56(70), 193-201 (doi: 10.3189/2015AoG70A953)

Garin C (1987) Inventario de glaciares de los Andes Chilenos desde los $18^{\circ}$ a los $32^{\circ}$ de latitud sur. Rev. Geogr. Norte Gd., 14, 34-48

Garreaud RD, Vuille M, Compagnucci R and Marengo J (2009) Present-day South American climate. Palaeogeogr. Palaeocl., 281(3-4), 180-195 (doi: 10.1016/j.palaeo.2007.10.032)

Gascoin S and 5 others (2011) Glacier contribution to streamflow in two headwaters of the Huasco River, Dry Andes of Chile. Cryosphere, 5(4), 1099-1113 (doi: 10.5194/tc-5-1099-2011)

Hall DK, Bayr KJ, Schöner W, Bindschadler RA and Chien JYL (2003) Consideration of the errors inherent in mapping historical glacier positions in Austria from the ground and space (1893-2001). Remote. Sens. Environ., 86(4), 566-577 (doi: 10.1016/S00344257(03)00134-2)

Le Quesne C, Acuna C, Boninsegna JA, Rivera A and Barichivich J (2009) Long-term glacier variations in the Central Andes of Argentina and Chile, inferred from historical records and treering reconstructed precipitation. Palaeogeogr. Palaeocl., 281(34), 334-344 (doi: 10.1016/j.palaeo.2008.01.039)

Leclercq PW and 5 others (2014) A data set of worldwide glacier length fluctuations. Cryosphere, 8(2), 659-672 (doi: 10.5194/ tc-8-659-2014)

Leiva JC (1999) Recent fluctuations of the Argentinian glaciers. Glob. Planet. Change., 22(1-4), 169-177 (doi: 10.1016/S0921-8181 (99)00034-X)

Lliboutry L (1956) Nieves y Glaciares de Chile: Fundamentos de Glaciologia. Editorial Universitaria, Santiago, Chile.

Lliboutry L (1998). Glaciers of South America I-6 - Glaciers of Chile and Argentina. In Williams JS and Ferrigno JG eds. Geological survey professional paper 1386-I, SATELLITE IMAGE ATLAS of glaciers of the world. United States government printing office, Washington, DC, USA.

Llorens RE and Leiva JC (1995) Glaciological studies in the high central andes using digital processing of satellite images. Mt. Res. Dev., 15(4), 323-330 (doi: 10.2307/3673808) 
Marangunic C (1979). Inventario de glaciares en la hoya del Rio Maipo. Dirección General de Aguas (DGA), Santiago, Chile.

Masiokas MH, Villalba R, Luckman BH, Le Quesne C and Aravena JC (2006) Snowpack variations in the central Andes of Argentina and Chile, 1951-2005: large-scale atmospheric influences and implications for water resources in the region. J. Climate., 19(24), 6334-6352 (doi: 10.1175/Jcli3969.1)

Masiokas MH and 5 others (2009) Glacier fluctuations in extratropical South America during the past 1000years. Palaeogeogr. Palaeoclimatol. Palaeoecol., 281(3), 242-268 (doi: 10.1016/j. palaeo.2009.08.006)

McClung DM (2013) The effects of El Niño and La Niña on snow and avalanche patterns in British Columbia, Canada, and central Chile. J. Glaciol., 59(216), 783-792 (doi: 10.3189/2013JoG 12J192)

Mernild SH and 6 others (2015) Mass loss and imbalance of glaciers along the Andes Cordillera to the sub-Antarctic islands. Glob. Planet. Change., 133, 109-119 (doi: 10.1016/j.gloplacha.2015.08.009)

Meza FJ, Wilks DS, Gurovich L and Bambach N (2012) Impacts of climate change on irrigated agriculture in the Maipo Basin, Chile: reliability of water rights and changes in the demand for irrigation. J. Water. Res. Pl., 138(5), 421-430 (doi: 10.1061/ (Asce)Wr.1943-5452.0000216)

Montecinos A and Aceituno P (2003) Seasonality of the ENSOrelated rainfall variability in central Chile and associated circulation anomalies. J. Climate., 16(2), 281-296 (doi: 10.1175/ 1520-0442(2003)016<0281:Soterr >2.0.Co;2)

Nicholson L and 5 others (2009) Glacier inventory of the upper Huasco valley, Norte Chico, Chile: glacier characteristics, glacier change and comparison with central Chile. Ann. Glaciol., 50(53), 111-118 (doi: 10.3189/172756410790595787)

Oerlemans J, Giesen RH and Van den Broeke MR (2009) Retreating alpine glaciers: increased melt rates due to accumulation of dust (Vadret da Morteratsch, Switzerland). J. Glaciol., 55(192), 729 736 (doi: 10.3189/002214309789470969)

Paul F and Andreassen LM (2009) A new glacier inventory for the Svartisen region, Norway, from Landsat ETM plus data: challenges and change assessment. J. Glaciol., 55(192), 607-618 (doi: 10.3189/002214309789471003)

Paul F and 19 others (2013) On the accuracy of glacier outlines derived from remote-sensing data. Ann. Glaciol., 54(63), 171182 (doi: 10.3189/2013AoG63A296)

Paul F and Molg N (2014) Hasty retreat of glaciers in northern Patagonia from 1985 to 2011. J. Glaciol., 60(224), 1033-1043 (doi: 10.3189/2014JoG14J104)

Pellicciotti F, Burlando P and Van Vliet K (2007). Recent trends in precipitation and streamflow in the Aconcagua River basin, central Chile Glacier mass balance changes and meltwater discharge. Foz do Iguaçu, International Association of Hydrological Sciences, IAHS. (IAHS assembly, selected papers 318).

Pellicciotti $F$ and 7 others (2008) A study of the energy balance and melt regime on Juncal Norte Glacier, semi-arid Andes of central
Chile, using melt models of different complexity. Hydrol. Process., 22(19), 3980-3997 (doi: 10.1002/hyp.7085)

Pellicciotti F, Ragettli S, Carenzo M and McPhee J (2014) Changes of glaciers in the Andes of Chile and priorities for future work. Sci. Total. Environ., 493, 1197-1210 (doi: 10.1016/j. scitotenv.2013.10.055)

Peña H and Nazarala B (1987). Snowmelt-runoff simulation model of a central Chile andean basin with relevant orographic effects. IAHS, Vancouver, Canada, vol. 166, 161-172.

Rabatel A, Castebrunet H, Favier V, Nicholson L and Kinnard C (2011) Glacier changes in the Pascua-Lama region, Chilean Andes (29 degrees $S$ ): recent mass balance and $50 \mathrm{yr}$ surface area variations. Cryosphere, 5(4), 1029-1041 (doi: 10.5194/tc5-1029-2011)

Rivera A, Acuna C and Lange H (2000) Variaciones recientes de glaciares en Chile. Investigaciones Geográficas, 34, 31

Rivera A, Acuna C, Casassa G and Bown F (2002) Use of remotely sensed and field data to estimate the contribution of Chilean glaciers to eustatic sea-level rise. Ann. Glaciol., 34, 367-372 (doi: 10.3189/172756402781817734)

Rosenbluth B, Fuenzalida HA and Aceituno P (1997) Recent temperature variations in southern South America. Int. J. Climatol., 17(1), 67-85 (doi: 10.1002/(Sici)1097-0088(199701)17:1<67:: Aid-Joc120>3.0.Co;2-G)

Rutllant J and Fuenzalida H (1991) Synoptic aspects of the central chile rainfall variability associated with the Southern Oscillation. Int. J. Climatol., 11(1), 63-76 (doi: 10.1002/ joc.3370110105)

Sandmeier S and Itten KI (1997) A physically-based model to correct atmospheric and illumination effects in optical satellite data of rugged terrain. IEEE Trans. Geosci. Remote Sens., 35(3), 708717 (doi: 10.1109/36.581991)

Shiyin L, Wenxin S, Yongping S and Gang L (2003) Glacier changes since the Little Ice Age maximum in the western Qilian Shan, northwest China, and consequences of glacier runoff for water supply. J. Glaciol., 49(164), 117-124 (doi: 10.3189/172756503781830926)

Tachikawa T and 12 others (2011). ASTER global digital elevation model version 2 - summary of validation results, NASA land processes. Distributed Active Archive Center and the Joint Japan-US ASTER Science Team, NASA.

Valdivia P (1984). Inventario de glaciares, Andes de Chile central (320-35o Lat. S.). Hoyas de los Ríos Aconcagua, Maipo, Cachapola y Tinguiririca. Direccion General De Aguas, Departamento de Hidrologia, Chile.

White A and Copland L (2015) Decadal-scale variations in glacier area changes across the Southern Patagonian Icefield since the 1970s. Arct. Antarct. Alp. Res., 47(1), 147-167 (doi: 10.1657/ Aaar0013-102)

Williams RS, Hall DK, Sigurdsson O and Chien JYL (1997) Comparison of satellite-derived with ground-based measurements of the fluctuations of the margins of Vatnajökull, Iceland. Ann. Glaciol., 24, 72-80 